aridity in the south-western area. This points to an antiquity even higher than that indicated by previous evidence.

\section{Liverpool Naturalists' Field Club}

THE seventy-sixth Annual Proceedings of the Liverpool Naturalists' Field Club, recently issued, covers the year 1936. The botanical notes include a summary by Mr. J. D. Massey of ninety new plant stations in the area recorded in the past four years since the compilation of Dr. Green's last "Flora of Liverpool", while Mr. W. S. Laverock, the botanical referee, describes the finding of deadly nightshade (Atropa belladonna) at Eastham, adder's tongue fern (Ophioglossum vulgatum) near the Manchester Ship Canal at Mount Manisty, young sycamore trees with variegated foliage at Irby woods, and other incidents of the field meetings of the year. The year's ornithological records, compiled by Mr. Eric Hardy, the ornithological referee, include a water-pipit, ruffs, a partalbino pied wagtail, curlew-sandpiper, little stint, greenshanks, green-sandpipers and a very late (November 28) yellow wagtail at Liverpool Sewage Farm, the latter (after a fog spell) a day later than the previous latest record in Britain; crossbills in the Ainsdale-Freshfield pinewoods in winter, a scaup wintering at the Botanic Park, Liverpool, puffins, forktailed petrels and mergansers in the Dee Estuary, a redwing summering in Knowsley Park and the nesting of the Canada goose and little grebe at Kirkby Dam, lesser black-backed gull and curlew at Simonswood, oyster-catcher and rock-pipit by the Ship Canal below Eastham, shoveller at Burton, grasshopper-warbler at Ince and Gayton in Wirral, and blackcap in Knowsley Park. The long-tailed duck is reported in full summer plumage feeding on crabs in West Kirby marine lake in mid-May. There are also the results of surveys carried out in the area for the British Trust for Ornithology, etc. The Committee reports an increase in membership during the year, the formation of a junior section, and an appeal for the Ornithological Fund.

\section{Review of Agriculture}

THE Royal Agricultural Society of England (16 Bedford Square, London, W.C.1) has published its ninety-seventh volume, which includes, as last year, the "Farmers' Guide to Agricultural Research". The latter consists of a review of research work in various branches of agriculture, each section being contributed by a recognized authority on the subject. The journal also contains a number of special articles on important questions such as housing the agricultural worker, labour, power and equipment in arable farming, the improvement of hill grazings and the technique of modern field experiments. On the animal side are articles dealing with the control of sheep ticks and systems of housing for pigs. The series on notable farm enterprises is continued, the Cambridge University Farm and Mr. Clyde Higgs's dairy farms being described in this number. The economics of farming are represented in an article on changes in beef imports before and after the Ottawa Agreement. The price of the journal is 158 .

\section{British Scientific and Technical Books}

A SELECT list of standard British scientific and technical books has been issued by the Association of Special Libraries and Information Bureaux. The list has been compiled at the request of the British Council and is planned as a guide in selecting books for a library. It is limited to about 300 works and is not a complete bibliography of the subjects covered, books out of print being omitted. Agriculture and medicine have been deliberately omitted, and the main purpose of the list is to assist in the choice of a collection of British scientific and technical books. Under each main section the books, so far as possible, are placed in a logical sequence of subjects, and it is intended that the ASLIB book list should provide a convenient means of keeping the select list up to date. The list contains a foreword by Sir William Bragg and an introduction by Sir Richard Gregory. The price of the list is $2 s$. to subscribers of the ASLIB book list and $2 s$. $6 d$. to non-subscribers.

\section{Preliminary General Catalogue of Comets}

VoL. 1, No. 4 of Publications of the Kuasan Observatory contains a catalogue of comets from the year 467 B.C. to the year A.D. 1936. The number of comets listed is 467 , and in each case the best available orbit with its reference source is given. The present catalogue is the revision of a catalogue published in 1931 by Prof. Issei Yamamoto in the Astronomical Yearbook of the Oriental Astronomical Association, printed in Japanese. This revised edition of the catalogue by his son, Prof. A. S. Yamamoto, who contributes a preface in English, will be very useful to all students of cometary orbits. A more comprehensive general catalogue is in course of preparation by these authors.

\section{Memorial to Sir Walter Morley Fletcher}

An account of the memorial to the late Sir Walter Morley Fletcher, secretary of the Medical Research Committee and Council in 1914-33, printed for the trustees of the memorial fund by the University Press, Oxford, has been issued to subscribers to the fund. It is illustrated with two plates, one of Miss Dora Clarke's posthumous portrait bust of Sir Walter Fletcher, photographed from the clay model, the other of a corner of the library of the National Institute for Medical Research with the finished bronze in position. After meeting the cost of this personal memorial, the balance of the fund is to be applied for a Walter Fletcher Memorial Laboratory at the Farm Laboratories of the National Institute at Mill Hill. The printed account contains appreciations of Sir Walter Fletcher by Prof. G. M. Trevelyan and Sir Gowland Hopkins.

\section{Rehabilitation of Persons Injured by Accidents}

THe Inter-Departmental Committee on the Rehabilitation of Persons injured by Accidents, set up jointly by the Home Office, Ministry of Health and Scottish Office, has issued an interim report (H.M. Stationery Office. $4 d$. net). This report deals particularly with the organization of "fracture clinics". 